\title{
Evaluation of Implementation of Election Villages Election Choice through the e-Voting System in Pemalang District 2018
}

\author{
Nunik Retno Herawati ${ }^{1}$, Fitriyah ${ }^{2}$ \\ \{nunikretno92@gmail.com ${ }^{1}$ \} \\ Universitas Diponegoro, Indonesia ${ }^{1,2}$
}

\begin{abstract}
This article tries to analyze how the Simultaneous Village Head Election Implementation Process using the e-voting system was carried out in Pemalang District in 2018 and analyze the strengths and weaknesses that occurred in the Simultaneous Village Head Election Implementation with the e-voting system in Pemalang District in 2018. The results of this evaluation can be a recommendation for improvement for the implementation of the Election of Village Heads using the upcoming e-voting system. The study uses descriptive research types using qualitative data analysis. Primary data collection was carried out using interviews with stakeholders as well as implementing Village Head Election in Pemalang District in 2018 in this case the Village Government Section of the Community Empowerment and Village Government Office (Dinpermasdes) of Pemalang Regency and the Communication and Information Office (Diskominfo) of Pemalang Regency. The results showed that the process carried out in the Election of Village Head e-Voting was very time efficient in terms of the verification process, the election process and the vote counting process (vote recapitulation). However, the queuing process apparently still occurs with this e-Voting system because the polling stations are less representative to be able to accommodate voters who are very enthusiastic about this e-Voting system.
\end{abstract}

Keywords: e-Voting, Election, Evaluation.

\section{Introduction}

Village Head Election, or abbreviated Village Head Election is an election held directly in the village by local villagers to elect the Village Head. Furthermore, the Election of Village Heads is the exercise of people's sovereignty in the village in order to elect Village Heads who are direct, public, free, confidential, honest, and fair. In article 31 of Law Number 6 of 2014 concerning Villages [1] it is explained that the Election of Village Heads is held simultaneously in all Regency/City areas. For this reason, the Regency/City Government shall determine the policy for the election of Village Heads simultaneously with Regency/City Regional Regulations. In the Regulation of the Minister of Home Affairs of the Republic of Indonesia Number 112 of 2014 Concerning the Election of Village Heads in the second part in article 2 , it is explained that the election of village heads is carried out simultaneously or can be bumpy [2]. The village head election is held once on the same day in all villages in the district/city area. The election of village heads in a bumpy manner is carried out by considering: Grouping the time period of the term of office of the Village Chief to expire in 
the Regency/City area; regional financial capacity; and/or the availability of Civil Servants in Regency/City environments that meet the requirements as acting Village Heads. Election of Village Heads in waves is carried out at most 3 (three) times in a period of 6 (six) years. The election of the corrugated Village Head as referred to shall be carried out with a time interval of no longer than 2 (two) years.

In 2018, Pemalang Regency held a simultaneous Election of Village Heads. The legal basis for the implementation of the Election of Village Heads in Pemalang Regency is Regional Regulation Number 1 of 2015 concerning Procedures for Election, Appointment and Dismissal of Village Heads, as amended by Regional Regulation Number 6 of 2017 concerning amendments to Regional Regulation Number 1 of 2015 concerning Procedures for Election, Appointment and dismissal of Village Heads and amended by Regional Regulation Number 10 of 2018 concerning Second Amendment to Regional Regulation Number 1 of 2015 concerning Procedures for Election, Appointment and Dismissal of Village Heads. While the Implementation Guidelines for Election of Village Heads in Pemalang District are based on Pemalang District Regulations number 36 of 2015 concerning Implementation Guidelines for Regional Regulation Number 1 of 2015 concerning Procedures for Election, Appointment and Dismissal of Village Heads, as amended in Pemalang District Regulations number 47 of 2018 concerning Amendment to Pemalang Regent Regulation number 36 of 2015 concerning Guidelines for Implementing Regional Regulation Number 1 of 2015 concerning Procedures for Election, Appointment and Dismissal of Village Heads. Based on the Decree of the Pemalang Regent Number: 141.1/386 of 2018 Concerning the Implementation of the Election of the Simultaneous Village Head Election in Pemalang Regency in 2018 the democratic party for the Election of Village Heads will be held in stages in 10 waves. A total of 172 villages in Pemalang Regency, Central Java will hold a simultaneous village head election. Interestingly, the Election of Village Heads of the north coast of Java will be carried out with an e-Voting system. The simultaneous election of Village Heads through the e-voting system in Pemalang District in 2018 is a continuation of the success of the Pilot Project. Election of Village Heads The e-Voting was held in Pemalang in 2016 in collaboration with BPPT and PT. INTI. In Decision of the Constitutional Court Number 147/PUU-VII/2009, the use of E Voting in Regional Head Elections or General Elections is said to be constitutional as long as it does not violate the expectations of Direct, Free, Secret, Honest and Fair General Elections. The further explanation states that the use of e-Voting must be based on objective considerations in the form of the readiness of the General and Community Election organizers, sources of funds and technology.

The implementation of the Election of Village Heads simultaneously, surging and using the e-Voting system is a quite complicated and complex political activity, moreover it involved 172 villages and was held for the first time simultaneously in Pemalang District [3]. Although it has been tested in 3 (three) Regencies in Indonesia, namely Jembrana, Boyolali Mahardika Satya [4] and Pemalang Burhanuddin Firmanyah [5], the implementation of evoting and e-verification is a new breakthrough where the implementation of the Election of Village Heads no longer uses paper ballot papers. This article tries to analyze how the Process of Executing the Election of Simultaneous Village Heads using the e-Voting system was carried out in Pemalang District in 2018. Furthermore, this article analyzes the strengths and weaknesses and weaknesses of the implementation of the Election of Simultaneous Village Heads using the e-Voting system carried out in Pemalang District 2018.

In the Regent's Decree Number 141.1/386 of 2018 Regarding the Implementation of the Election of Village Head Election in Pemalang Regency in 2018 it was stated that the Election 
of Village Head Election in Pemalang Tahuri Regency 2018 was held simultaneously with 10 (ten) stages [6].

Table 1. Election of Simultaneous Village Heads with Pemalang District e-Voting in 2018

\begin{tabular}{|c|l|c|}
\hline I & Sunday, September 2, 2018 & 18 village \\
\hline II & Sunday September 9, 2018 & 18 village \\
\hline III & Sunday, September 16, 2018 & 16 village \\
\hline IV & Sunday September 23, 2018 & 14 village \\
\hline V & Sunday September 30, 2018 village \\
\hline VI & Sunday October 7, 2018 & 18 village \\
\hline VII & Sunday October, 14 2018 & 18 village \\
\hline VIII & Sunday October 21, 2018 & 18 village \\
\hline IX & Sunday October 28, 2018 & 18 village \\
\hline X & Sunday November 4, 2018 & 18 village \\
\hline
\end{tabular}

Source: Data processed.

This article will analyze the simultaneous Election of Village Heads using the e-Voting system by focusing on the Voting stage because at this stage there was a substantial difference in the Manual Implementation Process of the Previous Village Heads manually (see Table 1).

Table 2. Difference between Manual Process and Electronic Process

\begin{tabular}{|l|l|}
\hline \multicolumn{1}{|c|}{ Village Head Election of Manual } & \multicolumn{1}{c|}{ Village Head Election of electronic } \\
\hline $\begin{array}{l}\text { Voters are verified manually according to DPT } \\
\text { manually }\end{array}$ & $\begin{array}{l}\text { Using a Laptop and verified using an Electronic } \\
\text { KTP }\end{array}$ \\
\hline $\begin{array}{l}\text { Ballots must be signed when voters are present } \\
\text { Directly to the Chamber }\end{array}$ & Ballots are available at the Chamber \\
\hline Stacking invitations and waiting to be called & $\begin{array}{l}\text { the Direct Chamber queued as they were present } \\
\text { and flowing }\end{array}$ \\
\hline
\end{tabular}

Source: Department of Community Empowerment in Pemalang Regency 2019.

\section{Research Methods}

This study uses descriptive research type using qualitative data analysis. Primary data collection was carried out using interviews with the Head of the Village Government Division of the Village Community Empowerment Office (Dinpermasdes) of Pemalang Regency as well as the Head of the e Division of the Government of the Office of Communication and Information (Diskominfo) of Pemalang Regency as the stakeholders on technical and e-voting tools. While secondary data is obtained from relevant documents such as various regulations, reports and news from the mass media. Both methods of collecting can collaborate to obtain the most valid data, but in the interests of certain data collection, this happens because not all data collection methods are taken in accordance with the type of data needed and the ability of the method itself in data collection. 


\section{Discussion}

Today, given the extraordinary Internet, e-voting and voting via the Internet are actually very often considered synonymous concepts. Internet voting systems can be classified into two main groups. If a ballot is cast by voters from a platform that is controlled and supervised by an election officer or polling officer, then it is called a polling internet polling site. Conversely, if voters cast their votes without supervision from a remote location, then it is called remote internet voting. Any voting method involving several electronic devices or systems can actually be considered "electronic". This certainly includes most of the modern democracies of the World election.

In theory, e-Voting and internet voting systems are different because voting can be carried out by 3 methods: first, by optical scanning method. This system is done by giving ballots to voters who then the results are recorded and counted electronically. This method must provide ballots that can be scanned with optics and require complicated designs and are expensive. This method is referred to as e-Counting.

The second method is Direct Recording Electronics (DRE). This method requires voters to cast their votes through a computer or touch screen or electronic board. Voting results are stored in memory at the TPS and can be sent both via the network and offline to the national vote counting center. Voters are still required to come to the polling station, but the vote counting data can already be stored and processed in real-time and online.

The third method is Internet Voting, where voters can give their voting rights from anywhere online via computers connected to the internet network. Internet voting may indeed offer several potential advantages over traditional voting methods: Reduction in costs for printing, distributing, collecting and tabulating ballots, Speed and accuracy of tabulation of ballot papers and recounting ballots, Greater voter mobility, Potential increase in turnout. However, the application of internet voting in elections must be done properly. Some technical problems must be carefully studied (and solved) to incorporate the Internet as a new medium to provide a binding vote, especially if voters choose to be allowed to choose from an Internet connection. From the spectrum of technical issues regarding the use of Internet voting for elections, security is currently considered the most important. Internet-based elections must therefore take into account (and fulfill) an extensive list of security requirements to ensure the integrity of the entire electoral process [7].

Thakur defines e-voting as an electronic way to vote and an electronic means for counting votes. E-voting can be done either in a controlled or uncontrolled environment. The Controlled Environment is a safe area while managing by installing equipment and implementing a clearly defined process flow. Uncontrolled environment refers to a situation where a voter accesses the system remotely from the comfort of his own locality (home, office or cellphone) and registers a vote [8].

Evolution in voting from conventional to electronic is expected to fulfill a number of criteria [9]:

a) Eligibility and Authentication, only valid voters can vote;

b) Uniqueness, no voter can vote more than once;

c) Accuracy, the electoral system must record votes correctly;

d) Integrity, sounds should not be modified, falsified, or deleted without detection;

e) Verification and Audit, it must be possible to verify that all votes have been properly counted in the final election calculation, and there must be a reliable and authentic General Election record; 
f) Reliability, the electoral system must work well, without losing votes, even in the face of many failures, including the failure of the voting machine and the total loss of internet communication;

g) Confidentiality and Non-Coercibility, no one must be able to determine how individuals vote, and voters should not be able to prove how they vote (which will facilitate the sale of votes or coercion);

h) Flexibility, the selection tools must allow for various formats of voting questions (for example, writing candidates, survey questions, various languages); compatible with various platforms and standard technologies; and can be accessed by people with disabilities;

i) Convenience, voters must be able to vote quickly with minimal equipment or skills;

j) Certification, the General Election system must be able to be tested so that General Election officials have confidence that they meet the required criteria;

k) Transparency, voters must be able to have general knowledge and understanding of the voting process; and

1) Cost effectiveness. Election systems must be affordable and efficient.

E-Voting in the Election of Village Heads in 2018 in Pemalang District was carried out using the second method, namely Direct Recording Electronic. There are several underlying BPPT using the DRE method including cheaper, accurate, verifiable and still maintaining the principle of Direct, General, Free Secret, Honest and Fair in the election process. Many possible benefits are identified when using an electronic voting machine. These include the ability to deal with complex elections, fewer staff polling, elimination of invalid ballots, faster counting, ballot standard decisions, accurate tabulation of results and new mechanisms to prevent fraud [10].

Election of Simultaneous Village Heads using the e-Voting system in Pemalang District in 2018 has advantages over manual Village Head Elections. The e-Voting system and technique must continue to fulfill the principles of LUBER JURDIL Democracy, namely Direct, General, Free, Honest and Fair Secrets. The e-Voting system is seen as having more value because it keeps the voters' choices a secret by encrypting and randomizing the order. From the results database, we won't be able to see who chooses what. The e-Voting system is also seen as more accurate because all the ballot papers are counted accurately. Voters' sign if they have chosen is printed audit receipt, taken by the voter and verified then put into the audit box.

Election of Simultaneous Village Heads using the e-Voting system in Pemalang District in 2018 is a breakthrough attempt to overcome the problems at the time of verification and voting that always occurs in the Election of Village Heads. The verification problem that often occurs is the existence of multiple voters, inappropriate voter domicile, fictitious Population Identification Number, abuse of invitations or the use of residual ballots. While on Election Day, the problem that often occurs is in the process of supplying, printing and distributing ballot papers. And at the time of vote counting, the problem that often occurs is the number of invalid ballots, there is a mismatch of the results of the manual calculation conducted by the executive committee with the results of the vote count done by witnesses or the public. In addition, the length of time needed to do the manual calculation process.

In article 72 of Pemalang Regent Regulation number 36 of 2015 concerning Implementation Guidelines for Regional Regulation Number 1 of 2015 concerning Procedures for Election, Appointment and Dismissal of Village Heads, the voting mechanism using electronic voting tools is: voters come to the polling stations, voters enter the polling station through the entrance provided by showing and submitting invitation letters and Electronic 
Resident Identity Cards, the polling officer examines the invitation letter and matches it to the Permanent Voter Register and ensures that the person concerned is a valid voter and has not used his right to vote or cast a ballot, if the voter uses an Electronic Identity Card, the voting officer examines the voter Electronic Identity Card with the help of a National Identity Card verifier to ensure that the Electronic Identity Card brought is legal and his property

At the stage of the verification process carried out by officers who are part of the Village committee, voters are required to bring an Electronic Identity Card. In the verification process it is not enough if the voters come to the polling place just by bringing an invitation. After the electronic Identity Card is read and verified, Present status will appear. Voters bring invitation letters that have been given a valid/suitable mark to be exchanged with smartcards to the $\mathrm{desk} /$ polling officer.
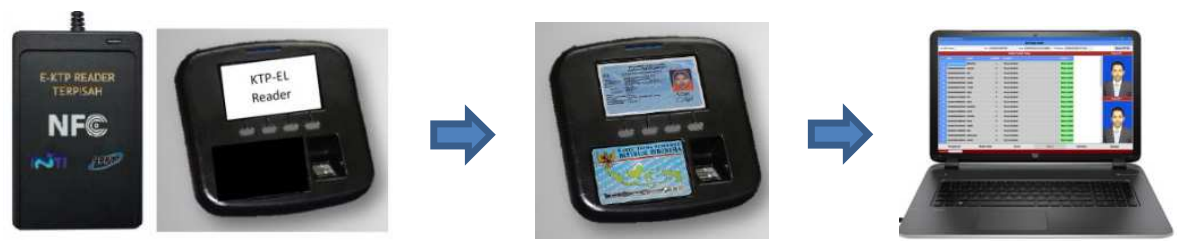

Fig. 1. Fixed Voter List Verification Process

Source: Technology Assessment and Application Board (BPPT) processed.

In the next stage, the clerk will receive a smartcard from the voter and insert the smartcard into the smartcard reader until a "please vote" sound is heard. If the Smartcard is not correctly entered it will not produce sound and is considered an invalid smartcard. The smartcard reading process lasts for 3 seconds. During this process the indicator light on the readier will blink (blinking green) for a while until it stops (electronic voice mail appears on the screen). If the candidate's image appears on the screen, voters are welcome to vote. After the candidate's image mark appears on the monitor, the selector touches once on one of the candidate's image marks of his choice. After the candidate's image mark is touched, a confirmation screen appears on the monitor screen in the form of "YES" and a green "V" in the box and "NO" and a red " $\mathrm{X}$ " in the box, to make sure the selection is correct or the choice is not correct. If the voter touches the words "YES" and the green sign "V" in the box, a receipt will come out as proof that the voter has used the right to vote. After the printer issues a printed receipt, the clerk will remove the smartcard from the smartcard reader and a "Thank You" sound will be heard. The printed receipt must be entered into the Audit box for later to be useful to match the results of electronic votes.

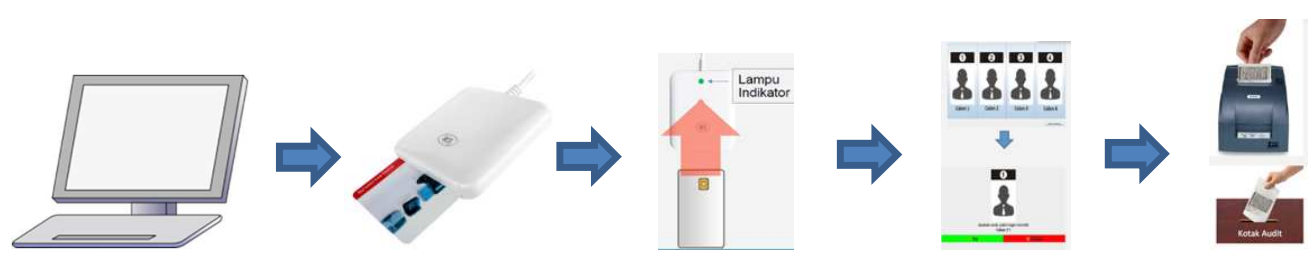

Fig. 2. Voting Process electronic Source: Technology Assessment and Application Board (BPPT) processed. 
Judging from the process carried out in the e-Voting Village Head Election, time efficiency can be seen from the verification process which only takes less than 10 seconds, the selection process is also very efficient because voters do not need to open the ballot paper, voters can simply touch the candidate image on the monitor. And the most efficient is the process of vote counting (vote recapitulation) which is very fast. The results of the vote count can be seen up to 30 minutes after the voting process is closed. The community can also immediately see the results of the vote count after the village head election process is closed from the website https://pemalangkab.go.id/evoting/ so there is no need to wait at the polling station. In addition to speed, the process of transparency and accountability will be realized with this e-voting system. An e-voting system can minimize the recalculation process that often occurs if the vote counting process is still done manually and avoids human errors. In the process of calculating the secrecy of the voters, it is very safe, because even though they use computers, this system is not connected to the internet either WAN or LAN. Internet use is only needed when sending the signed News Event to be uploaded in the data center.

There are several issues that are noted in the process of implementing the simultaneous Election of Village Heads with the e-Voting system in Pemalang District in 2018. First, the queuing process apparently still occurs with this e-Voting system [11]. This happens because people's behavior when they vote in the Village Head Election is different from the Legislative Election and the Election of President and Vice President. In the process of Election of Village Heads, the community will usually come to the polling station collectively with the Candidate Winning Team for Candidates for Village Heads. Second, polling stations are less representative to accommodate large numbers of voters and are able to protect tools from the weather. Due to limited space in the village hall, the process of implementing the Election of Village Heads in Pemalang Regency uses school facilities (elementary, junior high, high school), but the problem is the door is not designed to enter and exit, as a result an emergency exit is created which of course requires time and cost.

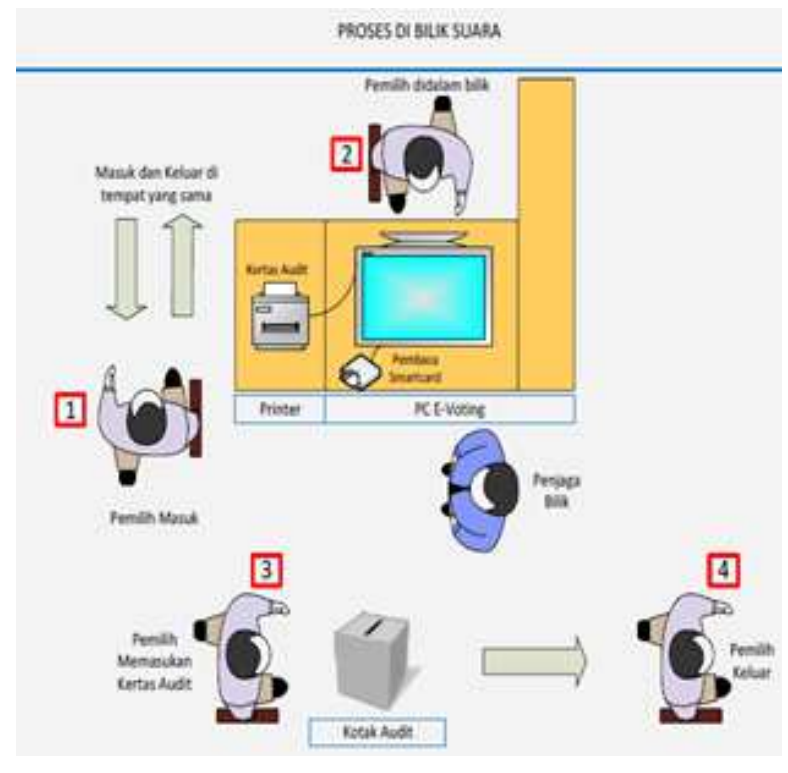

Fig. 3. Ideal Booth Layout

Source: Technology Assessment and Application Board (BPPT). 
The third note is the absence of a waiting room that is comfortable enough for voters who will use their voting rights. From the facts on the ground there are still many voters who are overheated in the yard to wait for the time to vote.

\section{Conclusion}

The implementation of the Election of Village Heads by e-Voting is simple and not as complicated as the people imagined. In the Election of Village Heads by e-Voting the owner of the vote is enough to attach a Resident Identity Card, and then verified with his left or right index fingerprint. Voting is quite easy to do by touching the image mark on the computer's touch screen available in the voting booth. The ease of village head election with the e-Voting system can also be seen from the speed of the results of the village head election which immediately appeared after the voting process was declared complete. Of course, this is different from the conventional electoral system which must pass the vote counting stage.

\section{References}

[1] U.-U. Nomor, "tahun 2014 tentang Desa." 6AD.

[2] "Regulation of the Minister of Home Affairs of the Republic of Indonesia Number 112 of 2014 concerning Election of Village Heads." .

[3] M. Ridlo, "Sophisticated Pilkades e-Voting System in Pemalang," 2018. [Online]. Available: https://www.liputan6.com/regional/read/3634211/c sophisticatednya-pilkades-sistem-e-votingdi-pemalang.

[4] M. Satya, "Implementation of Electronic Voting Policy in the Election of Village Heads in Boyolali Regency in 2013," Diponegoro University Semarang, 2017.

[5] B. Firmansyah, "Implementation of Electronic Voting (E-Voting) Policy in the Election of Village Heads in Pemalang Regency in 2016," Diponegoro University, Semarang, 2018.

[6] "Regent Decree Number 141.1 / 386 / Year 2018 Concerning Implementation of Voting in the Election of Simultaneous Village Heads in Pemalang Regency in 2018." .

[7] A. Riera, J. Sànchez, and L. Torras, "Internet voting: embracing technology in electoral processes," in Electronic Government: Design, Applications and Management, IGI Global, 2002, pp. 78-98.

[8] S. Thakur, "Overview of E-Voting - Cross-National Experienc," South Africa, 2013.

[9] C. D. Mote Jr, "Report of the national workshop on internet voting: issues and research agenda," in Proceedings of the 2002 annual national conference on Digital government research, 2002, pp. 1-59.

[10] J. B. Esteve, B. Goldsmith, and J. Turner, "International experience with e-voting," Nor. E-Vote Proj. Int. Found. Elect. Syst. Doc. Dispon. online la Adres. http//www. ifes. org/Content/Publications/News-in-Brief/2012/June/\% 7E/media/B7FB434187E943C18F4D4992A4EF75DA. pdf, 2012.

[11] S. Bachri, "Regent of Pemalang Criticism of Election Voting Electronic Election." [Online]. Available: https://www.suaramerdeka.com/news/baca/121237/bupati-pemalang-kritik-pilkadesvoting-electronics. 